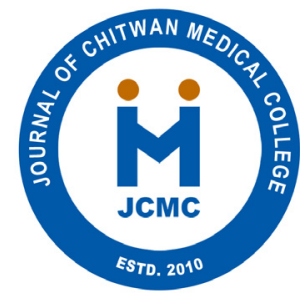

Journal of Chitwan Medical College 2013,3(3): 18-21

Available online at: www.jcmc.cmc.edu.np

ORIGINAL RESEARCH ARTICLE

\title{
GENDER DIFFERENCES IN DEPRESSIVE DISORDER AMONG CIVIL SERVANTS OF PUBLIC SERVICE UNDER GOVERNMENT OF NEPAL
}

\author{
PAryal $^{1^{*}}$, A Aryal $^{2}$, H Ghimire ${ }^{3}$ and KP Bista ${ }^{4}$ \\ ${ }^{1}$ Ministry of Energy, Singh Durbar, Kathmandu, Nepal. \\ ${ }^{2}$ CARE International, Kathmandu, Nepal. \\ ${ }^{3}$ Department of Community Medicine and Public Health, Chitwan Medical College, Bharatpur-10, Chitwan, Nepal. \\ ${ }^{4}$ Family Planning Association of Nepal, Harihar Bhawan, Pulchowk, Lalitpur, Nepal \\ *Correspondence to : Ms Parbati Aryal, Ministry of Energy, Singh Durbar, Kathmandu, Nepal.E-mail: parbati.aryal@yahoo.com
}

\begin{abstract}
This study aims to measure prevalence of depression among civil servants of public service in central Nepal from gender perspectives. Zung Depression Scale was used to measure the depression among randomly selected 161 civil servants employed in public service under government of Nepal in Kathmandu and Chitwan districts. Three-fourth of the respondents (74.5\%) were normal, $19.3 \%$ had minimal to mild depression, $4.3 \%$ had moderate to marked depression, and $1.9 \%$ had severe to extreme depression. Among women, $4.2 \%$ had severe to extreme depression, while $29.2 \%$ had minimal to mild depression and $66.7 \%$ were normal. Among men, $1.5 \%$ had severe to extreme depression, $5.1 \%$ had moderate to marked depression, $17.5 \%$ had minimal to mild depression and $75.9 \%$ were normal. Women were at 1.58 times higher risk of depression than that of men $(0.56<\mathrm{OR}>4.37)$. From high prevalence of depression among the civil servants of public service, it is apparent that mental health problem needs immediate attention in workplace. As women workers were more likely to have severe to extreme form of depression, appropriate gender-friendly workplace policies and strategies should be designed to address the mental health of public service providers in Nepal.
\end{abstract}

Key Words: Depression, Gender, Civil Servants, Workers, Nepal \& Zung Depression Scale

\section{INTRODUCTION}

At workplace, women and men are exposed to different physical and psychological stressors in services. ${ }^{3}$ In general, the problems associated with men's work are better known, since men do visibly heavy work such as mining, cutting trees, fishing and building construction. From 1960 to 1997, women have increased their numbers in the global labour force by $126 \% 5$ and they make up about $42 \%$ of the estimated global working population as indispensable contributors to world economy. ${ }^{1}$ Women's work related injuries and diseases are even less accurately reported, since women's work is generally regarded as so called safe. Women's occupation $\neg$ al health problems are under diagnosed. Women usually suffer discrimination and sexual harassment more often than men in their occupations and are also more likely to suffer from intimidation including mobbing and psychological harassment. ${ }^{4}$

Although not many psychological differences between women and men have been demonstrated scientifically, it has been suggested that men have higher self-esteem and confidence and that women are more emotionally expressive. ${ }^{2}$ No study was found measuring depression among civil servants of public service in Nepal at the best of our knowledge either in electronic or print media. This study aimed to measure the prevalence of depressive disorder among civil servants of public service in Nepal and explore its nature among men and women civil servants in central Nepal in order to highlight the necessity to strengthen and put programmes and practices at work in place to ensure men's and women's mental health \& safety more and better.

\section{MATERIALS AND METHODS}

This is an analytical cross-sectional study. The study area was the public sector, i.e. governmental sector of Nepal. The work sites particularly considered were Kathmandu \& Chitwan districts consisting of employees of civil service of Nepal.

The study subjects were the employee in the public sector, i.e. governmental sector of Nepal, selected from different services at first level of sampling. In second level of sampling, a combination of study subjects from different levels of gazetted and non-gazetted services within those services were ensured. Considering 75209 employees as per the record of Nijamati 
Kitab Khana, Ministry of General Administration/HMG/ Nepal: 2003, the sample size was calculated using Epi-Info 2000 (Satcalc) for the cross-sectional survey. The estimation of parameters for this study is done based on the parameters found from previous studies and statistical accuracy and power sought by the general studies conducted in social and health dimensions. The parameters and background estimates used for calculating the sample size were confidence interval $95 \%$, expected frequency of disease (depression) $10 \%$ and worst acceptable error $5 \%$.

Minimum calculated sample size for the cross-sectional study as calculated by Epi Info was 138. The expected response rate was $80 \%$. To increase the validity, it was decided to study $20 \%$ more sample units in addition to the minimum calculated sample size. Thus, the final minimum calculated sample size under study was 166 . To cover this, a total of 170 questionnaires were administered. The response rate was more than expected, i.e. 95\%. Altogether 161 respondents responded to the questionnaire. This sample represents even if the number of employees increased by $20 \%$ per year from 2003 to 2007 .

Multi-stage sampling was used for this study. The researcher decided to sample different workplace settings and services within the public sector of Nepal. Simple random sampling was used to draw the sample of the different staff categories in the different services under public sector. Exhaustive list of population under different offices and services was obtained from Nijamati Kitabkhana.

The data were collected administering a standard questionnaire to each of the respondents. The questionnaire contained three sections. Section I contained Demographic profile of the respondent. Section II contained Work Profile. Section III contained Zung Depression Scale.

The data were analyzed using statistical software namely SPSS version 13.0. Magnitude and nature of depression was analyzed with respect to different variables. Descriptive statistics was used to characterize socio-demographic characteristics and nature of depression of the workers.

Before administering the questionnaire, the objectives of the study, information sought from the respondents, benefits and the risks of the study for the respondents were explained. Voluntary verbal consent was obtained from the respondents and it was ensured that personal information provided by them would be kept anonymous \& confidential.

\section{RESULTS AND DISCUSSION}

The general characteristics, status of anxiety and that of depression were found as follows.

\section{Socio-demographic characteristics}

The mean age of the respondents was 35.04 years with the standard deviation of 7.75 years. The maximum age is 59 years and minimum age 22 years with a range of 37 years, which almost represents the age of civil service workers. Majority of the respondents $(85.1 \%)$ were men, while only $14.9 \%$ were women. Majority of the respondents (32.9\%) had completed Bachelor's level education followed by Intermediate level (25\%), Master (21.1\%), and secondary education (14.5\%). Some of them were also merely literate $(5.3 \%)$ and only 1.3 percent had lower secondary level education (Table 1).

Table 1: Socio-demographic characteristics of respondents

\begin{tabular}{|l|l|c|c|}
\hline Characteristics & Statistics & $\mathbf{n}$ & $\mathbf{\%}$ \\
\hline Sex $(\mathrm{n}=161)$ & Women & 24 & 14.9 \\
\hline & Men & 137 & 85.1 \\
\hline $\begin{array}{l}\text { Educational status } \\
(\mathrm{n}=152)\end{array}$ & Lower secondary & 2 & 1.3 \\
\hline & Secondary & 22 & 14.5 \\
\hline & Intermediate & 38 & 25 \\
\hline & Bachelor & 50 & 32.9 \\
\hline & Master & 32 & 21.1 \\
\hline & Literate only & 8 & 5.3 \\
\hline
\end{tabular}

Mean and Standard Deviation of age 35.04 and 7.75 and minimum and maximum age was 22 and 59 respectively.

\section{Service of workers}

Three fourth of the respondents $(75 \%)$ were involved in nontechnical service while about one-fourth of them $(25 \%)$ were engaged in technical service. Two third of the respondents $(66.7 \%)$ reported of being engaged in administrative tasks at work while one-third (33.3\%) mentioned that their work is of technical More than half of the respondents $(55.9 \%)$ were from civil service (civil service ), nearly one fourth (23\%) were from security service followed by $13.7 \%$ from education, and $7.5 \%$ from health service.

Majority of the respondents $(24.2 \%)$ were from administration group followed by army/ police $(21.7 \%)$, legal $(19.5 \%)$, teaching $(13.8 \%)$, taxation $(5.7 \%)$, health inspection $(4.4 \%)$, miscellaneous $(3.8 \%)$ and others $(6.3 \%)$. Majority of the respondents $(40.6 \%)$ were non-gazetted first class level workers of Nepal government followed by non-gazetted second (20\%), gazetted 3rd third (16.1\%), non-gazetted third (10.3\%), levelless $(9.7 \%)$ and gazetted second (3.2\%) (Table 2$)$. 
Table 2: Types of services of respondents

\begin{tabular}{|c|c|c|}
\hline Characteristics & $\mathbf{n}$ & $\%$ \\
\hline \multicolumn{3}{|c|}{ Type of services $(n=160)$} \\
\hline Technical & 40 & 25 \\
\hline Non-Technical & 120 & 75 \\
\hline \multicolumn{3}{|c|}{ Type of practical work $(n=156)$} \\
\hline Administrative & 104 & 66.7 \\
\hline Technical & 52 & 33.3 \\
\hline \multicolumn{3}{|l|}{ Services $(n=161)$} \\
\hline Civil Service & 90 & 55.9 \\
\hline Health & 12 & 7.5 \\
\hline Education & 22 & 13.7 \\
\hline Security & 37 & 23 \\
\hline \multicolumn{3}{|l|}{ Group $(n=159)$} \\
\hline Legal & 31 & 19.5 \\
\hline Administration & 39 & 24.5 \\
\hline Health inspection & 7 & 4.4 \\
\hline Miscellaneous & 6 & 3.8 \\
\hline Teaching & 22 & 13.8 \\
\hline Army/Police & 35 & 22 \\
\hline Taxation & 9 & 5.7 \\
\hline Others & 10 & 6.3 \\
\hline \multicolumn{3}{|l|}{ Level $(n=155)$} \\
\hline Gazetted 2nd & 5 & 3.2 \\
\hline Gazetted 3rd & 25 & 16.1 \\
\hline Non-gazetted 1st & 63 & 40.6 \\
\hline Non-gazetted 2nd & 31 & 20 \\
\hline Non-gazetted 3rd & 16 & 10.3 \\
\hline Levelless & 15 & 9.7 \\
\hline
\end{tabular}

\section{Depression among workers}

The mean scores of workers in Zung Depression Inventory were found to be 33.47 with the standard deviation of 8.73 . The maximum and minimum scores were 62 and 20. The mean total SDS Index scores for depression were 42.01 with standard deviation of 10.91. The maximum and minimum SDS index scores were 78 and 25 respectively (Table 3 ).

Table 3: Total scores of workers in Zung Depression Inventory and Zung Self-Rating Depression Scale (SDS) Index

\begin{tabular}{|l|l|}
\hline \multicolumn{2}{|c|}{ Zung Depression Inventory Scores } \\
\hline Mean & 33.47 \\
\hline Std. Deviation & 8.73 \\
\hline Minimum & 20 \\
\hline Maximum & 62 \\
\hline \multicolumn{2}{|c|}{ SDS Index Scores } \\
\hline Mean & 42.01 \\
\hline Minimum & 25 \\
\hline Maximum & 78 \\
\hline
\end{tabular}

Of the respondents $(n=161), 74.5 \%$ had no psychopathology, i.e. were normal when $25.5 \%$ had depression. Minimal to mild depression was found in $19.3 \%$ of the total respondents. Moderate to marked depression was found in $4.3 \%$ of the respondents and severe to extreme depression was detected among $1.9 \%$ of the respondents (Table 4 ).

Table 4: Type of depression in workers

\begin{tabular}{|l|c|c|}
\hline Status of depression (n=161) & Number & Percent \\
\hline No psychopathology (Normal) & 120 & 74.5 \\
\hline Minimal to mild depression & 31 & 19.3 \\
\hline Moderate to marked depression & 7 & 4.3 \\
\hline Severe to extreme depression & 3 & 1.9 \\
\hline
\end{tabular}

Among women $(n=24), 66.7 \%$ had no psychopathology, i.e. were normal when $33.3 \%$ had depression. Of them $(n=24)$, $4.2 \%$ had severe to extreme depression and $29.2 \%$ had minimal to mild depression. Among men $(n=137), 75.9 \%$ had no psychopathology, i.e. were normal when $24.1 \%$ had depression. Of them $(n=137), 1.5 \%$ had extreme depression, $5.1 \%$ had moderate to marked depression and $17.5 \%$ had minimal to mild depression. Women were at 1.58 times higher risk of depression than that of men $(0.56<\mathrm{OR}>4.37)$ (Table 5). 
Table 5: Types of depression in relation to gender

\begin{tabular}{|c|c|c|c|c|c|}
\hline \multirow{2}{*}{ Sex of civil servants } & \multicolumn{5}{|c|}{ Type of depression in civil servants } \\
\cline { 2 - 6 } & $\begin{array}{c}\text { No psycho-pathology } \\
\text { (normal) }\end{array}$ & $\begin{array}{c}\text { Minimal to mild } \\
\text { depression }\end{array}$ & $\begin{array}{c}\text { Moderate to } \\
\text { marked depression }\end{array}$ & $\begin{array}{c}\text { Severe to extreme } \\
\text { depression }\end{array}$ & $\begin{array}{c}\text { Total } \\
1(4.2 \%)\end{array}$ \\
\hline Women & $16(66.7 \%)$ & $7(29.2 \%)$ & $0(0.0 \%)$ & $24(100.0 \%)$ \\
\hline Men & $104(75.9 \%)$ & $24(17.5 \%)$ & $7(5.1 \%)$ & $2(1.5 \%)$ & $137(100.0 \%)$ \\
\hline Total & $120(74.5 \%)$ & $31(19.3 \%)$ & $7(4.3 \%)$ & $3(1.9 \%)$ & $161(100.0 \%)$ \\
\hline
\end{tabular}

\section{DISCUSSION}

In total, one-fourth of the government employees of central Nepal including one-third of women and one-forth of men were living with depression. The results are consistent with other studies conducted among civil servants 8 , which showed that depression is more prevalent among women than their male counterparts.

Women public servants of Nepal were at 1.58 times higher risk of depression than that of men $(0.56<\mathrm{OR}>4.37)$. The increased risk of depression among Nepalese women engaged in public sector job than that of men might be associated with higher working hours 7 as Nepalese women they have to engage in overtime household work in addition to their regular office work. The limitation of this study is small sample size, especially of women engaged in government service, which demands for further study on determinants of different types of depression among men and women in Nepal.

\section{CONCLUSION}

In total, more than one-forth of personnel in public service sector have been suffering from depression. Depression was detected among one-third of women and one-forth of men working in public service sector. From high prevalence of depression among the workers of public service sector, it is apparent that mental health problem needs immediate attention in workplace. As women workers were more likely to have severe to extreme form of depression, appropriate gender-friendly workplace policies and strategies should be designed to address the mental health of civil service providers of public service in Nepal.

\section{ACKNOWLEDGEMENT}

We are thankful to Mr. Shankar Bhandari, Associate Professor, Trichandra College for his technical contribution in this study.

\section{REFERENCES}

1. International Labour Office (ILO). Yearbook. Geneva, International Labour Office, 2000.

2. Lindelow M, Bildt-Thorbjornsson C. Psychological differences between men and women. 1998. In: Kilbom Å, Messing K, Bildt Thorbjörnsson C, editors. Women's health at work. National Institute of Working Life. 61-98.

3. Messing K, Punnett L, Bond M, Alexanderson K, et el. Be the fairest of them all: challenges and recommendations for the treatment of gender in occupational health research. American Journal of Industrial Medicine 2003;43:618-629.

4. Paoli P, Merllie D. Third European survey on working conditions 2000 Dublin: European Foundation for the Improvement of Living and Working Conditions. http:// www.eurofound.eu.int/publications/files/EF0121EN.pdf. 2001.

5. World Bank. Engendering development. New York, Oxford University Press 2001.

6. World Health Organization. Occupational health, ethically correct, economically sound. Geneva, World Health Organization. Fact Sheet Nr 84:1999.

7. Virtanen M, Stansfeld SA, Fuhrer R, Ferrie JE, Kivimäki M Overtime Work as a Predictor of Major Depressive Episode: A 5-Year Follow-Up of the Whitehall II Study. PLoS ONE 7(1): e30719. doi:10.1371/journal.pone.0030719. 2012.

8. YusufAF, Adeoye EA. Prevalence and causes of depression among civil servants in Osun State 2007: Implications for counselling.

9. Winikoff B, Ellertson C, Elui B, Sivin I. Acceptability and Feasibility of early pregnancy termination by mifepristonemisoprostol. Archives Family Medicine 1998;7:360-366. 